\title{
Grey Zone in Caribbean Islands: Socio-Racial Struggles around the Martinican Carnival
}

\author{
Patrick Bruneteaux
}

Researcher, CNRS (National Centre for Scientific Research), University Paris 1 Pantheon-Sorbonne, France.

etropic 14.2 (2015):30-43. http://www.reefandleaf.com.au/etropic.html $\&$ http://www.jcu.edu.au/etropic

\begin{abstract}
Few researchers have attempted to show that colonialism was associated with an on-going task of division between slaves. This article intends to highlight the functioning logic of the colonial plantation world. In the Caribbean area, whether that of English, Dutch, Spanish or French colonialisms, the morphological existence of a minority of Whites and an overwhelming majority of Blacks in a permanent state of rebellion, as Patterson's (1982) work demonstrated, was the basis for the creation of intermediate groups as "buffers". These auxiliary people (domestics, hunters of fugitives, executioners, free people in militias; but also, by mimicry, the Black owners of slaves) are only part of a larger system requiring a strong dependency between the free people of color, that is of mixed heritage - Mulatres in French colonies, Mulattos in English colonies ${ }^{1}$ - and White masters. This model of the tripartition between the rich White class, the free middle class of mixed heritage, and the proletarian Black people, can define itself as a society in which the "colortocracy" (Anderson, 2000) became a "grey zone" in the sense of Primo Lévi's (1989) analysis of Nazi concentration camps. Neither subaltern studies nor the social science of creolization really bind this social stratification to long-lasting effects of domination between Blacks themselves. Nowadays, the political power is detained by this brown upper class. Thereby, this type of socio-racial structure has been maintained long after the official demise of colonialism and it continues to affect the political and economic organization of Caribbean islands. In this rigid framework, in which individuals and people are increasingly dominated (structural joblessness, migration to the metropole, racism and whitening, lack of economic independence etc.), the Black proletarians have developed a counter-culture among which the best known forms are carnival and a daily Maroon behavior, namely many protean resistances against the White world and colortocracy. This paper discusses the situation of the Martinican carnaval taking place on the French island of Martinique.
\end{abstract}

\footnotetext{
${ }^{1}$ The French colonial term Mulâtre, Mulatresse, previously considered offensive, is now reclaimed by many Caribbean Islanders.
} 


\title{
Grey Zone in Caribbean Islands
}

\begin{abstract}
As long as human beings believed in some form or another, that life was subject to supernatural forces, the carnival maintained its meaning. From the moment where everything was regulated by municipal policies or criteria based on 'social order' and 'good taste', the carnival was nothing but a poor bourgeois entertainment.
\end{abstract}

Julio Caro Baroja (1979). Le Carnaval, Paris, Gallimard, p. 25-26. [My translation]

In the introduction to his famous book Social Conflict and Social Movements, Anthony Oberschall (1973) noticed that studies relating to the "old colonies" were written as if the process of colonization had been concluded and the studies conclusive. Owing to a considerable amount of research carried out by his predecessors, the studies relating to the nationalist movements in the old colonies and the civil conflicts of post-independence in the new State were considered definitively established. Researchers in the social sciences had studied these movements in order to understand the processes of mobilisation and the formation of new states, but were much less interested in the links between the social properties of old colonial elites and the process of their conversion under social and political change.

However, it is important to question the continuation of the old colonial subjections, even through new forms of "collaboration" in economic dependency. In the wake of recent research, it is possible to stress the fact that the very concept of independence is a problem in itself. The outward shape of a State shouldn't be considered as an acquired fact and rarely matches with the local sovereign power. The notions of State or independence deserve further examination regarding the parameters of their reality, "State" after "State", in order to test their degree of "sovereign power" (Gilmore 1985; Fowler \& Bunk, 1996). According to these authors' criteria, many Caribbean states, but also former colonial ones, shouldn't be called states. The impact of imperialism, dependence, allegiance to the worldwide market, and ideological alignment to the "metropole" (mainland), continue to alter the progress of the former colonised islands which have become formal states (Lowenthal, 1970; Gafar, 1988; Heine, 1990; Payne, 1994; Bogues, 2002).

The issue remains even thornier when one looks into the elites having given up any process of independence. Within this framework the case of Martinique is particularly interesting. For decades, since the abolition of slavery in 1848, the local elites have expected that their links to the French State would be maintained. Taking electoral results as a reference, these elites put forward their demand for "equality" between themselves and the "Metropole" (mainland France), pointing out that the people are not mature enough for independence, using the example of Haiti as a scarecrow. Glissant (1981, p. 206), in his book Le Discours antillais, states that the ruling class can be qualified as "the incredible pusillanimity of elites having exchanged independence for citizenship". This request for "equality" hides a strategic renouncement which has been made visible in the socio-history of the colonial links of dependence. As such, the concept of colonial dependence constitutes a two-way conceptual rupture. It is a break first in the sense that those who proclaim the entry into "postcolonialism" forget the effects of inertia in the reproduction of social structures. The 
"departmentalisation" ${ }^{2}$ of 1946 hides the preservation of the previous economic and social frames. This event also introduces a break because "inheritance" is a controversial issue. Jurisdiction and equalisation are the proof of even stronger shades of neocolonial links to the Metropole.

One of the major indicators of this neocolonial order is linked with the perpetuation of the economic-political system of agricultural monoculture ${ }^{3}$, in other words, the dependency on exportation. Another one is the reproduction of socio-racial groups, and to an even greater extent, the reproduction of these groups and the uninterrupted presence of social links of loyalty and dependency between Black elites and the old White elites on all Caribbean islands (Dungy, 2005; Loomba, 1998; Pons, 2007). The system continues to exist and organises itself around the Black elites ("Mulattos"). This "grey zone" (Levi, 1989) comes from a totalitarian space in which colonial violence required different kinds of intermediary groups who helped the masters. Because of the numerical disproportion between Blacks and Whites, the slave owners needed to use what Orlando Patterson has called the buffer (1982). The permanent fear by White owners of a state of rebellion spawned an area of surveillance all around the plantations through the bodies of freed slaves. These allies, freed by masters, sometimes became rich and important asserting political rights in all the Caribbean islands. These groups and categories known as "Free people of color" led an independent life and formed an originating upper class. Occupying different positions of economic and political power, from Louisiana to Brazil, they became what Elijah Anderson calls the "colortocracy" (2000).

Binary distinctions such as Blacks and Whites, settlers and colonised, slave owners and victims should be avoided. For when considering the structural necessity of the grey zone, it becomes possible to distinguish the implementation of a specific social process. Once we get past the structural logic of binarism we may have a chance to make more meaningful and rapid progress in understanding the phenomenon of Caribbean colonialism and its long-term effects. When one analyses research carried out in the Caribbean regarding a similar issue it becomes apparent that the answer has been largely the same. The founding sociologist of Black Cultural Studies, Stuart Hall (1996), and his follower, Paul Gilroy (1985), have never studied these intermediate groups. Hall and Gilroy maintain superficial contrasts between English-speaking and French-speaking island logics (Hall, 1996)

Colonial phenomenon is by its very nature closely linked to the idea of structural homogeneity between Black and White elites: with a lower intensity on the Hispanic islands, the minority of White colonial owners have lived with local Black "assistants". More numerous Spaniards, like the Americans of the USA, kept an upper hand on the repressive

\footnotetext{
2 In France, in 1946, the colonised islands became DOM (départements d'outre mer, overseas departments), that is, administrative units of the French Republic, while some of the French islands in the Indian Ocean and the Pacific have the French administrative status as TOM (territoires d'outre mer, overseas territories). In 2003, the DOM islands (Réunion, Guadeloupe, Martinique, Guyane) became DOM-ROM (overseas departements and regions). The TOM were replaced by COM (Collectivités d'outre-mer, overseas collectivities), except for Mayotte and Saint-Pierre-et-Miquelon, and the Terres australes which remained TOM. French Polynesia and New Caledonia became POM (Pays d'outre-mer, overseas countries) with their own parliament but without independence. The independence of New Caledonia is to be decided through a future referendum.

${ }^{3}$ The monoculture of one product (banana, sugar) had dire consequences on the abilities of "old colonies" to become economically and politically independent. For instance, in Martinique, after one week of strikes, the land cannot feed its population. That means the island has to import all food from France.
} 
groups (the "Ranchadores" from Cuba or the settler's militia in the south of the US). However, most plantations of the English, French and Dutch are aligned with the model of the grey zone: using special troops, the militia, commandeurs and household servants, as repressive groups in the use of social control. These repressive groups then became, outside of the plantation, a kind of middle class themselves. An upper class - an economic and political elite - emerged from the latter (Keith \& Herring, 1991). The Black bourgeoisie originates from its links of dependence to the system, what I call "the Forgotten Colonialism" (Bruneteaux, 2013), a socio-racial system established by the European Empires in the Caribbean as much as in Black America. In all of the Americas (apart from the USA and to a lesser extent the Hispanic Islands), a continued tripartition between a minority of Whites, an intermediary group of Mulattoes and a majority of poor Black people has been perpetuated (Eisner, 1961; Wallace, 1961; Hollister, 1969; Layne, 1979; Baksh, 1979; Baronov \& Yelvington, 2003; Bodenhorn, 2006). Post-colonialism is thus more often neocolonialism.

\section{The role of carnival in socio-racial issues}

The Martinican Carnival (Bruneteaux \& Rochais, 2013) is not considered one of the biggest carnivals in the Caribbean, but for the island's population, it is one of the main highlights of collective life. In the Caribbean as a whole, and more globally in the Black Americas (Van Koningsbruggen, 1997; Agier, 2000), a large portion of the population take part in these festivities. It is difficult to say whether the participants mainly arise from the most dominated strata of the population. However, the majority of the gatherings involve Black people. From the 1920/1930s, White settlers gradually became more distant from carnivals (Bruneteaux \& Rochais, 2006), and in the 1960/1970s metropolitan middle classes followed suit (Bruneteaux, 2013). Nowadays, there are groups of metropolitan tourists or people from the mainland coming to work on the island who may also participate in carnivals. However, as is the case in Guadeloupe, very few White people participate in the festivities, some even avoid it.

The rate of participation of "Mulattoes" and "Black people" in the carnival is difficult to estimate. In 1950/1960, demonstrations were localised, every village organising its own festivities. In most rural districts, social inversion was meant to mock deviants and political figures in equal measure. All the testimonies indicate that the popular faiths accompanied the release of the most magical religious characters of the pantheon (red devils, she-devils). On the sidelines of the official celebrations in one's community (Queen's election, balls, private parties), where the local municipal power and metropolitan technocracy mingled, the working classes occupied the streets. Up until the 1960s, the carnival of the poorest, which represented the vast majority of Martinican people, was taking place in small villages where peasants and the working class lived. As articulated by one of the managers of the Carnival, City Hall, Fort de France:

We had the carnival of the people. People took a bag of flour, made four holes and launched into the street. And there was also this carnival called bourgeois.

Nowadays, we can no longer describe it in those terms, as it has been commercialized. The old clothes we do not put them on any more. Thus the economic dimension has become increasingly important. There was this 'decline'. Not everybody participated at the same time. The White creole were excluded and also Mulattoes. It's normal as far as in the Vidés, there were songs which mocked them. There was some kind of charivaris against the elected local officials, against the White creole and against people who prepared the events. Here was a real subversive dimension 
although the carnivals were never social movements. It was a social tension which released itself, it was a valve where people expressed their frustrations following strike actions aiming at such or such, or following some prohibitions of the ordinary life. For example, there was an owner who declared that people were not allowed to touch what belonged to him. He was ransacked by a kids band party in which I took part.

Denunciation of power and denunciation of deviance are intertwined. Sometimes, the carnival worked as a space of reiteration of standards. The manufacturing of fictitious characters (the bwa bwa from the neighborhood) allowed any resident to denounce, with the support of collectivity, behavioral deviations (adultery, quasi-incest in a union between cousins). As recalled by an inhabitant of Saint Joseph:

\begin{abstract}
Formerly, in all the villages and sometimes even in most districts of villages, there were people who created with their own initiative a character who was going to be ridiculed: Vaval, that we called previously bwa bwa. Most of the time, in Saint Joseph, it was the flute player which performed the song of Vaval. At some point, he shouted: 'is that him?' 'Yes, it is him' answered the assistance. You could not escape it; you were obliged to recognize it yourself. In every district of the village there was a person who chose the theme. Most of the time it was someone who had done something stupid. For example, in my district the woman who created the bwa bwa 'raised' a cousin that had adulterous relationships. There was always a drawing of the head which was very similar to him.
\end{abstract}

Formerly, this popular jubilation was a collective one and formed a group, with a central place and a parade where everybody got together. In this shared space, some took back the songs putting into mockery the $b w a b w a$ of the year, others disguised themselves by putting on a traditional character or by inventing a new style. In the evening they went to the renowned bars which involved jousts between dancers and music players. In the $1950 \mathrm{~s} / 1980 \mathrm{~s}$, members of the popular neighborhoods organised parades that came from their neighborhood to conquer "l'en-ville". "L'en-ville", according to Patrick Chamoiseau (Chancé, 2013), was the living place inside beautiful traditional stone and wood houses of bourgeois families or Mulattoes until the beginning of the 1980s when festivals made a gradual retreat from certain upper class districts of Fort de France ("Didier") and close by the town ("Schoelcher", "Terreville" and "Fond Lahaye"). The managers of Tambour Bo Kanal, a poor district area adjoining the port of Fort de France, explained that one could have up to 1,000 people there in "l'en-ville" throwing themselves into the street leading to the city center. In Trinidad, "during the 1920s and 1930s, domestic servants also constituted a highly politicized group... that pertained to Afro-Creole women. These concerns were sometimes presented as part of the Carnival tradition" (Franco, 1998, p. 73). Today, this association tries to preserve its values but it also looks for agreements with the political power, which means trying to integrate young drifters. Before discussing this issue further, it seems that this tension between low-income groups and the instrumental political reaction of what should be politically correct is the transcript, in the carnival, of socio-racial struggles in the French Islands of the Americas. Martinique is above all a cartography of socio-racial classes turned into geographic castes. The belt around Fort de France hosting the ancient proletariat of plantations (thus coming from slaves) became a precarious proletariat and a zone of massive poverty and underemployment. As in inner districts of some French cities (Toulon, Grasses, 
Marseille), the centre was abandoned to the working classes and given over to the subproletariat.

As in Brazil, during the Carnival, the White creole and the Mulattoes of Martinique often leave the island by plane for a few days. There used to be collective practices of popular protest movements. Today, the official carnival of parades has been gentrified. Nowadays the Mulattoes withdraw to their residences according to a complex movement which involves territorialisation (recently constructed districts and the re-use of family gardens) and a cultural system which associates fear of disorder with moral-religious disgust. However, they also simultaneously participate fully in the daily organisation of the carnival in connection with Black political elites committed to local development including the arrival of shopping malls, a growing consumer society, and mass tourism coming from the Metropole. From the 1980s, with the arrival of tourists, the city of Fort de France has progressively invested in the parade's organisation.

Indeed, the middle class became essentially an aesthetic and/or folk logic, with groups like the Bibas Committee or Plastic System Band (Scher, 2002; Mulot, 2003; Bruneteaux, 2013), peaking in the 2000s with the organisation of contests and awarding of prizes for the best carnival group. These were called "groupes à pied" because they are music groups centred around percussion instruments with people walking in close rows on the street - petty bourgeoisie resolutely playing the game of elites, surfing on the root of traditional values. For them, to speak about roots means being well dressed in bright colors, and the cost of this clothing has increased excessively. In order to make these costumes some people look for subsidies, or just pay the high prices; but the majority of the population stock up cheaply from the Syrano-Lebanese' markets. As in the Bahia popular carnival, there are almost no people in fancy-dress or amusing costume in the street, except the "groupes à pied" in competition. However, for people coming from the working class using percussion and masks is more important than getting dressed up and winning a prize. The slum district of Tambour Bo Kanal is an excellent example. The symbolic image of their roots is the flapper. The impression might be created that freedom exists for poor people in theses festivities, however, it is most often the cultural petite bourgeoisie, such as teachers, that guide people in the working class areas. The economic, touristic, aesthetic dimension of the official carnival, which is also increasingly found in Trinidad (Scher, 2002) or in Brazil (Rio versus Bahia), has ensured places for the very festive social actors who come from all social classes but has also, especially, made a place for the orderly and hedonistic middle class.

It is symptomatic to observe during the prize-giving ceremony the mass withdrawal of the working class, even though very poor districts surround the festival hall which was created by Aimé Césaire. Similarly, Mulattoes and petite bourgeoisie, having cultural capital, have invested in the carnival, especially since the 1990s, with a strong push of policies inherited from the past, and the taste for the history of practices and objects. Elites and petty bourgeoisie have found themselves in cultural organisations. They divide the two opposite sides. Some have become well-known, like Tambour Bo Kanal, Akyo or Voukoum in Martinique and Guadeloupe. But whereas these leaders join the working class and claim for representation of slavery and barbarism, other members of the middle class enter in the aesthetic carnival. One of the most recognised users of conch in the French Caribbean is an anthropologist from a well-known Mulatto family. He is one of the most well-known representatives of this carnival of traditional festivities. This aesthetic carnival is now a well ordered and tidy one. 
Carnival participants are organized in "foot walking groups" (groupes à pied), collective organisations which parade in the sound of percussions, or, individual aggregated people in crowds that follow the rhythms of sound systems of regional radios, whose origin is European or American. Middle class has reinvested in the carnival, whereas lower classes have become partial spectators or have invented other dissidences, particularly as deviants.

\section{Poor classes at the margins of Carnival}

With the arrival of the carnival show, members of the poorest class have significantly shifted their practices. Now, next to the orderly official parades, the majority of the people have been relegated to the status of spectators; except for the young people, who, whether from urban poor areas or not, gather around music to dance.

Another part of the poor class, that which is highly religious, has disconnected itself from these festivities because of the increased power of the Protestant church. Many people I interviewed in poor urban areas or met during religious festivities (meetings of Adventists, dances and prayers of Evangelic people, pilgrimage to Notre Dame de la Délivrande among Catholics) consider that this immoral and devilish carnival is dangerous and not interesting.

Those who remained involved in the carnival were navigating in small informal groups. As a consequence, the poor are less present in these collective ordered formations, which have become calm and "clean" official demonstrations.

When the dominated stay, they take part in the carnival in a different way, to the great displeasure of Mulatto patronesses who denounce the carnival's immorality. They condemn it on radios, and in the unique newspaper (France-Antilles) which is the voice of Mulattoes and French elites. As organisers, the Mulattoes's rare testimonies of carnival give strong evidence of these positions. Therefore, the Black people of poor areas react in two ways to the official, moralistic order of the carnival. They either remain in the manner determined by the current carnival frame, or leave it and produce another carnival. In other words, they create a counter face of the carnival against the Mulatto's carnival - a real social inversion. The popular carnival has thus developed itself on the edges of, and in parallel to, the bourgeois carnival, as the working class stopped attending the latter, deeming it to be a touristic folk carnival. A joyful popular carnival also exists, the vidés of the young people.

The ideology of a Martinican carnival bringing together all the constituents of the society is an illusion, in reality the socio-racial structure of social classes is expressed in the form of divided groups of action reflecting the neocolonial structure of the society. This margin is simultaneously clairvoyant and discreet. It is discreet in the sense that during les jours gras ${ }^{4}$ the day is respected by all people, even by "bad boys" as French Martinicans, using English, refer to young men from the slums or shanty towns. However, even though these "bad boys" follow the parade, they do so without taking part in it. They stay on their scooters and look at the show.

Carnival deviancy expressing itself in the sense of the carnival repertoire refers essentially to a physical inversion, where men, especially, overinvest in sex and nudity. The first element of the carnival is the sexual component. The theme of sexual license is a classic one in the study

\footnotetext{
${ }^{4}$ The so-called "fat days" leading up to Lent. During this period, inhabitants celebrate the most intense moments of the carnival.
} 
of European carnivals since the Middle Ages. The urge to let go of oneself with excessive behavior communicates itself through two types of characters: the Makoume and the Malpropres. The most numerous makoumè are dressed in little feminine fineries, positing eroticism and an obscenity based on the exaggeration and mixture of genders. They are similar to a prostitute overloaded with signs, raising a skin-tight dress to reveal a very short pair of shorts or a G-string to clearly expose a provocating body. They voluntarily adopt a male attitude and some of their male physical characteristics. Never showing themselves as naked, one guesses genitalia through skin-tight dresses. Showing their hairiness, they keep male attitudes. Their hairy legs, tattoos and masculine traits are on show. They may wear dresses, but with sneakers (rather than high heals). This allows them to maintain a manly attitude. Holding a beer can or a cigarette in their hands, these Makoumè with deep voices and hearty laughter generally circulate in small noisy groups, coming and going as part of a groupe à pied. These men display their manliness in such a way that it represents women as inferior. This gender inversion is well known and shows up at all the carnivals of the socalled Afro-American people, from Louisiana to Brazil. It's rather "vulgar" and popular, especially in Martinique or Trinidad, and to a certain extent in Bahia.

The Malpropres ("The Unclean") represent the second pole of the popular demonstrations of the naked body. Through the trashiest pop-culture, the revealing of excrement, or feminine pads displaying menstrual blood, they introduce the notion of soiling to shock people from the middle class. Numerous people, perched on old cars, display pornographic photos while making their engines roar and portraying themselves as babies wearing used diapers.

Much of this work around the naked body also has a political connotation. In a carnival including the lower class of the population, it is expected that racial demonstrations will shape one part of the festivities. The "Black is beautiful" is thus raised to fame through characters which were created several decades ago and have never disappeared. For instance, the Neg Gwo Siro opposes itself to the beautiful folk colors of the Bibas group which sings the natural heritage of Caribbean identity (Bruneteaux \& Rochais, 2010a). The symbol of negritude is represented by these Black men, strong and "dangerous". These ancient "Black slaves" participate in the restoration of dignity amongst the Black population whose marronage (the freedom of the Maroons, or escaped slaves) is celebrated. Almost naked, coated with molasses and gleaming, they formerly carried a seal with which they splashed the passers-by.

The abnormality expressing itself in the social inversion is mainly acted out by young people, particularly in favelas, barrios or slums all around the world, in order to enter forms of dissidence and use of warlike capital (Venkatesh, 2009; Sauvadet, 2006). The contesting of the Mulatto carnival essentially comes from young people in poor areas, either from former shanty towns of the belt around Fort de France (Rochais, 2012), or housing projects of the villages. It is a kind of carnival within a carnival, an implicit denunciation of a rejected carnival which they cannot appropriate themselves. The technicalisation of the parades involves knowing how to dance, follow a rhythm, play an instrument, and buying a costume. It relegates the poorest families or those who, being unable to become identified within the musical frame (the drum is a fundamental popular instrument associated with dances of slaves, like Bélé or Ladja), do not find themselves in the ordered staging of the parades.

While in the 1950s all research and popular press agreed that children and teenagers followed the adults in role play based on transvestites, it is now obvious that "poor teenagers" have become spectators. However, by joining together in external groups with scooters they also 
refuse to participate in the overly-formalised and civilised events controlled by local elites. In the meantime, schools urge their young children to participate and dance in the formalized festivities, in an attempt to socialize them. School folklorisation, through its military style, betrays the original freedom of the carnival and imposes a regimentation of festivities as part of compulsory education. All carnival participants are duly recorded/registered before the competition if they want to obtain a subsidy from the city hall. The cultural manager in charge of the carnival who I interviewed recognised this regimentation. In general, the age bracket of 15 to 30 year olds, coming from working class districts, get involved in the carnival in the following ways: by shocking middle-class people, by disturbing the procession with scooters, by plundering businesses, by showing up as "bad boys", by crashing the private parties of rich people and consuming foodstuffs, or by fighting with a rival gang on its territory during demonstrations. It is the festive social life around the carnival which is the object of denunciation.

\begin{abstract}
Many young ghetto people from 13 to 25 years old are bored. It is for them the opportunity to explode. These teenagers have no mark. They are excluded by society. The carnival is the pretext for everything. It is the opportunity for people who know that they do exist to show themselves. They claim an identity... It is necessary to show who is the strongest. They come quite equipped as they say: backpacks, scarves, sodarhum. These teenagers come to let off steam. Anything can happen in this moment where they can let go and escape from everyday life. They make 'devil cocktails' made of gasoline and beer to get high, going hell for leather. They only see 'Babylon'. That is why they challenge the authorities, everybody, and even the carnival itself. They say: 'We are at home here'. And they are taking on all those who are not considered part of this world. ${ }^{5}$
\end{abstract}

From then on, these young men do not join the festivities in the spirit of producing a carnival of transgression but to introduce an external social transgression. Their very real inversion targets the carnival itself in order to produce effects of ruptures: cancellation of parades after riots and plunders, diffusion of fear, and the propagation of feelings of incomprehension among the middle class. Opportunities for disorder open a window to another reality: disturbance of the parade with motorcycles aiming to frighten the participants, imposing the representation of "bad boys", fighting with the police, etc.

\title{
Countering the carnival in the carnival: the "Mulattoes" and their attempts to reframe the deviant Black people.
}

The carnival implementation process cannot be separated from the society's overall functioning in which it takes place. Far from believing, as the Brazilian Da Matta, that the carnival is a space which minimizes, or momentarily, erases the divisions of society; it is necessary to bear in mind, as does Agier (2000), that it constitutes a conflictual double, another place where class and race struggles are expressed.

The first reaction of the ruling class is to denounce the behavior of popular teenagers, and to engage in the disciplining of parades. During carnival, the teenagers of the underclass know that they are going to oppose a security power whose goal is to control them directly. For

\footnotetext{
${ }^{5}$ Interview with a police officer of Sainte-Luce (March 2004), one of the carnival towns during the 2004 festivities.
} 
instance, devices to neutralise the underclass teenagers, based on a security budget of a third part of the total budget spent by the city of Fort de France for the carnival, were announced with many interviews with individuals in charge of this security service. During the RFO/ATV news program broadcast at 7 pm, on Thursday, February 3, 2005, the journalists relayed the political and police authorities' message: "A key word for the carnival: safety". The authorities will "take security measures. It will be necessary to channel, to supervise the population and to secure the businesses", to control "undisciplined people and to call for vigilance". The journalists, in their reports call for the "discipline of the public". The carnival as a specific moment where social tensions are expressed is inseparable from, and intrinsically linked to, social issues. Violence in the street is generated by these symbolic and institutional violences. Internal island tensions are more and more exacerbated: $50 \%$ of the young people are unemployed, rejecting an exotic and touristic country in which they cannot have a place (Bruneteaux \& Kabile, 2012). But the carnival has to be disciplined, especially when working class behaviour is considered deviant for mainstream society.

Another effect of this gentrification revolves around the denunciation of traditional practices. "Pornography" is denounced by politicians, intellectuals and the main organisers of the carnival $^{6}$. This is in contrast to the youth from the slums who, in the spirit of the folk festival associate "pornographic posters on old cars... in their head [with] a symbol of freedom"7. Sex and its parody, which can traumatise public consciousness, is used as a weapon against social order. A technocrat of the carnival explains:

"That always existed. The problem is the balance. In the 70s, during one of my mother's last visits she came down in the carnival, there were people who saw nuns looking at the carnival. They showed their sex. They had a right to be there. The carnival is not inevitably something dirty or devilish. And mothers looked. And the Malpropres began to show [expose] themselves" (March 2004, Sainte Luce).

Another manager of the city hall of Fort de France in charge of the carnival generalised this denunciation of the indecency of these characters by taking himself to Makoumè:

"It is true that we always had men dressed as a woman. Men were very sexy but the sexuality did not overflow so much. It is something new. But we had a lesson. What do we want as carnival?"

Whether stemming from high-level bureaucrats or stemming from the middle class, this kind of carnival reveals globally its opposition to the lower class members' practices, whatever their modality of appearance (disguise of the body, the uses of motorcycle, the use of Bwadjaks - old cars). What the Black working class can't master in economic and political life, many men hope here to control through sexual debauchery. Their beliefs or representations in free sexuality are often violent against women in the very act of denunciation of the order. The ambivalent position of working class males, low income groups, or unskilled men, is a very old finding of structural sociology and cultural anthropology of racially segregated slums, in the vein of W.E.B. Dubois or E.F. Frazier (Lewis 1966; Anderson 1976, 1999; Liebow, [1967] 2010; Bourgois \& Schoenberg, 2009; Venkatesh, 2008). These findings, as in French colonial studies (Glissant, 1981; Giraud,

\footnotetext{
${ }^{6}$ Like the mulatto Grazielle Bontemps, Committee Chair Carnival, France Antilles, 15 February 1967.

${ }^{7}$ Interview with a former member of the carnival's federation, October 2004.
} 
1998) or in Caribbean studies (Mohammed, 1998; Chevannes, 2001), show that this violence against women in post-cultural societies, and aggressive sexual practices, come from what is called "le dérobé de la jouissance sexuelle" (the stolen sexual enjoyment). This is expressed by a tendency of immediacy, acts of violence, and an inclination to engage in polygamy or multiple relationships, which is seen as enhancing masculinity. These indicate effects in the present time which have been representations of a fugitive and/or a predatory slave sexuality for centuries.

But the carnival has a social aspect as well, as it is also located in poor areas and aims at solving problems with social policies designed to help the same young people. During the preparation of the carnival educators and social workers try to integrate rebel teenagers in the groupes à pied of their home space. It is then a question of keeping them in line, of orchestrating them within the global partition of the carnival. In other words, to integrate them into the aesthetic groupes à pied. It is as though the ruling class had used the rite with the aim to make a routine. It is as though the elites had used this out of the ordinary timespace of the carnival to make an even stronger tool in the fight against social struggles, as the interview dialogues below attest to:

\section{You said that there were young people in the groupes à pied...}

Do you think that young people who are in conservatoires, who learn about classical authors or piano are spontaneously going to go to street orchestras? No, because they already have a release, they already have an activity. By subtraction, it is at first those who do absolutely nothing or who have nothing to eat (rien à se mettre sous la dent, "nothing to put under the tooth") or who have no means to approach music who are going to join the street, the so-called street orchestra. Now it is true that street educators opened the street orchestras by formally integrating lost young people. It is an argument for the search for subsidy. There are street orchestras which at first are in an association and very clearly take this path. The group Tambour bo Kanal, is an example. 99\% of the people in the group Plastic system band, have a job. There are elected members, managers. They do not have this concern. (Martinican town policeman)

\section{It would be rather middle class...}

And even more. There are many groups in which there is no social concern. For others, the social function arises from the fact that it can be a space for these young people.... At the moment, it is a place of collective expression. The social issue is all the same there. It is a minority that thinks we ought to take charge of teenagers who waste their time hanging around on street corners. It is said these young people become more and more apparent in the groupes à pied. We say it in a more and more explicit way that the groupes à pied are also on this path. (Martinican town policeman)

In conclusion, this paper argues that far from being a social invention, the carnival is also the continuation of socio-racial struggles. A continuation in the sense of an erosion by the ruling class practices of a stage which was traditionally appropriated by the working class. In the sense also of an inversion of this official inversion when the troublemakers reappear and look for attention. But marginality still frames and invalidates practices of the working class in the eyes of most people. Having been dispossessed of their sociality, most rebel representatives 
of the working classes are invited to go into the ranks of the authorised and devitalised carnival. And the Mulattoes remove their secular right to exist for a moment in this somewhere else which, it is necessary to say, always frightened the powerful. Now, by trying to avert this fear, they are only igniting the social-racial issues.

\section{Works Cited}

Agier M. (2000). Anthropologie du carnaval. La ville, la fête et la ville à Bahia, Editions Parenthèses/IRD.

Anderson E. (1976). A Place on the Corner. Chicago: University of Chicago Press.

Anderson E. (1999) Codes of the Street. Decency, Violence and the Moral Life of the Inner City. New York: Norton \& Company.

Anderson E. (2000). The Emerging Philadelphia African American Black Class Structure. Annals of the American Academy of Political and Social Science, 568, 54-77.

Baksh I.J. (1979). Stereotypes of Negroes and East Indians in Trinidad: A Re-Examination. Caribbean Quarterly, 25 (1/2), 52-71.

Bodenhorn H. (2006). Colorism, Complexion Homogamy and Household Weath: Some Historical Evidence. The American Economic review, 96 (2), 256-260.

Bogues A. (2002) Politics, Nation and PostColony: Caribbean Inflections. Small Axe, 11 (1), $1-30$.

Bourgois P. \& Schoenberg. J. (2009). Righteous Dopefiend. Berkeley and Los Angeles: University of California Press.

Bruneteaux P. \& Rochais, V. (2006). Le carnaval des travestis. Les travestis Makoumè, Martinique : Editions Lafontaine.

Bruneteaux P. \& Rochais, V. (2009) La mise en scène de la sexualité masculine dans le carnaval martiniquais: entre inversion sexuelle et obscénité conformiste. In R. Beauthier, J.M. Méon, B. Truffin, Les mises en scènes de la sexualité et leur (dis)qualification. Bruxelles: Université Libre de Bruxelles.

http://digistore.bib.ulb.ac.be/2010/noncat000024 000 f.pdf

Bruneteaux P. \& Rochais, V. (2010a). Couleurs sur corps noirs et carnaval à la Martinique. In G. Boëtsch, D. Chevé \& C. Claudot-Hawad, Décors des corps (pp. 231-241). Paris : Editions du CNRS.

Bruneteaux P. \& Rochais, V. (2010b). Le carnaval des travestis makoumè à la Martinique. Quelques propositions sur le sens de l'inversion sexuelle. In B. Ndagano (Dir.), Penser le Carnaval. Variations, discours et représentations (pp.113-137). Paris: Karthala.

Bruneteaux P \& Kabile, J. (2012). L'innovation dans l'insertion. Rapport pour le Ministère de l'Outre-mer, CRPLC/Paris1, janvier.

Bruneteaux P. \& Rochais, V. (2013). Carnaval martiniquais et rites de passage. In I. Hidair et L. Pourchez (Dir), Rites de passage et constructions identitaires dans le monde créole (pp.207-216). Paris : Editions des Archives contemporaines.

Bruneteaux P. (2013). Le colonialisme oublié. De la zone grise plantationnaire aux élites mulâtres à la Martinique. Bellecombe-en-Bauges : Le Croquant.

Chancé D. (2013). De l'anticolonialisme à la créolisation : les écrivains postcoloniaux des Antilles françaises. In M. Bernardot \& P. Bruneteaux, Quel colonialisme dans la France d'Outre-mer, Asylon(s), TERRA, 11, Mai.

Chevannes B. (2001). Learning to Be a Man: Culture, Socialization, and Gender Identity in Five Caribbean Communities. Barbados: University of the West Indies Press. 
Dungy K.R. (2005). Live and Let Live: Native and Immigrant Free People of Color in Early Nineteenth Century Puerto Rico. Caribbean studies, 33 (1), 79-111.

Eisner G. (1961). Jamaica, 1830-1930: A Study in Economic Growth. Manchester: Manchester University Press.

Fowler M. R. \& Bunk, J. M. (1996). What Constitutes the Sovereign State? Review of International Studies, 22 (4), 381-404.

Franco P.R. (1998). 'Dressing up and Looking Good': Afro-Creole Female Maskers in Trinidad Carnival. African Arts, 31 (2), 62-96.

Gafar J.S. (1988). The Anatomy of Unemployment in a Third World Country: Jamaica. 19681984. Caribbean Studies, 21 (3/4), 71-90.

Gilmore W.C. (1985). Legal and Institutional Aspect of the organization of Eastern Caribbean States. Review of International Studies, 11 (4), 311-328.

Giraud M. (1997). Entre particularités épidémiologiques et spécificités culturelles : 1'enquête sur les comportements sexuels aux Antilles et en Guyane françaises. Sciences sociales et santé, 15 (4), 73-95.

Glissant E. (1981). Le discours antillais. Paris : Gallimard.

Hall S. (1996). Cultural Identity and Cinematic Representation. In H.A. Baker, M. Diawara \& R.H. Lindeborg, Black British Cultural Studies (pp. 210-222). Chicago \& London: University of Chicago Press.

Heine J. (1990). A Revolution Aborted: The Lessons of Grenada. Pittsburgh: University of Pittsburgh Press.

Hollister F.J. (1969). Skin Color and Life Chances of Puerto Ricans. Caribbean Studies, 9 (3), 87-94.

Lévi P. (1989). Les naufragés et les rescapés. Quarante ans après Auschwitz. Paris: Gallimard.

Lewis O. (1966). La Vida. A Puerto Rican Family in the Culture of Poverty, San Juan and New York. New York: Random House.

Lowenthal A.F. (1970). The United States and The Dominican Republic to 1965: Background to Intervention. Caribbean Studies, 10 (2), 30-55.

Keith V.W. \& Herring, C. (1991). Skin Tone and Stratification in the Black Community. American Journal of Sociology, 97 (3), 760-778.

Layne A. (1979). Race, Class and Development in Barbados. Caribbean Quarterly, 25 (1/2), 40-51.

Mason P. (1998). Bacchanal. The Carnival Culture of Trinidad. Philadelphia: Temple University Press.

Mohammed P. (1998). Rethinking Caribbean Difference. In P. Mohammed (Ed). Rethinking Caribbean Difference: Feminist Review (pp.1-5). Issue 59. Routledge.

Mulot S. (2003). La trace des masques. Identité guadeloupéenne entre pratiques et discours. Ethnologie française, 33 (1), 531-549.

Obershall A. (1973). Social Conflict and Social Movements. Englewood Cliffs: Prentice Hall.

Patterson O. (1982). Slavery and Social Death. A Comparative Study. Cambridge, London: Harvard University Press.

Pons F.M. (2007). History of the Caribbean: Plantations, Trade, and War in the Atlantic World. Princeton: Markus Wiener Publishers.

Sauvadet T. (2006). Le capital guerrier, concurrence et solidarité entre jeunes de cité. Paris : Armand Colin.

Scher P.W. (2002). Copyright Heritage: Preservation, Carnival and The State in Trinidad. Anthropological Quarterly, 75 (3), 453-484.

Van Koningsbruggen P. (1997) Trinidad Carnival. London: Warwick University Caribbean Studies. 
Venkatesh S. (2009). Gang Leader for a Day. London and New York: Penguin Books.

Wallace E. (1961). The West Indies: Improbable Federation? The Canadian Journal of Economics and Political Science, 27 (4), 444-459. 